U.S. Department of the Interior

U.S. Geological Survey

\title{
Regional CuRVe DeVelopment and SELECTION OF A REFERENCE REACH IN THE NON-URBan, LoWLAND SECTIONS OF THE Piedmont Physiographic Province, Pennsylvania ANd MaryLAND
}

by Kirk E. White

Water-Resources Investigations Report 01-4146

In cooperation with the

PENNSYLVANIA DEPARTMENT OF ENVIRONMENTAL PROTECTION 


\title{
U.S. DEPARTMENT OF THE INTERIOR
}

\section{GALE A. NORTON, Secretary}

\author{
U.S. GEOLOGICAL SURVEY
}

Charles G. Groat, Director

For additional information write to:

\section{District Chief}

U.S. Geological Survey, WRD

215 Limekiln Road

New Cumberland, Pennsylvania 17070-2424

Email: dc_pa@usgs.gov
Copies of this report may be purchased from:

U.S. Geological Survey Branch of Information Services Box 25286

Denver, Colorado 80225-0286

Telephone: 1-888-ASK-USGS 


\section{CONTENTS}

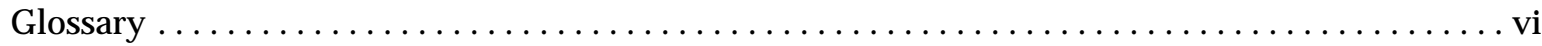

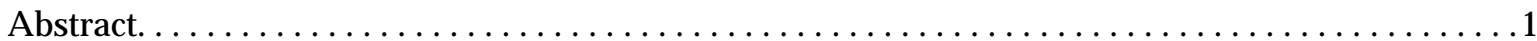

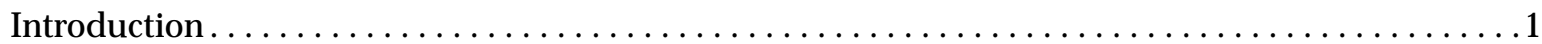

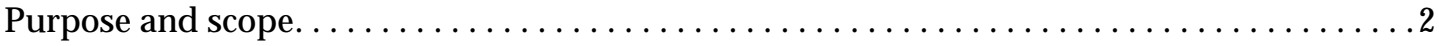

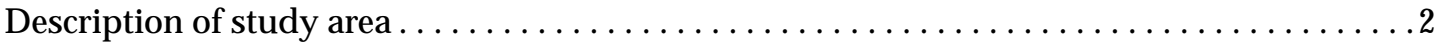

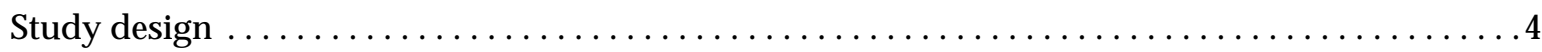

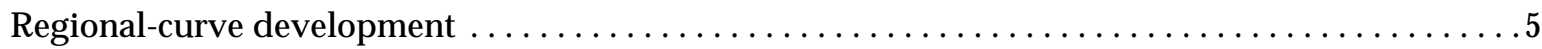

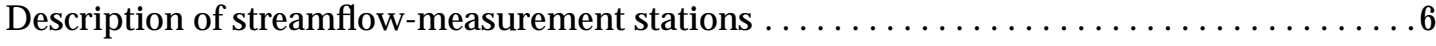

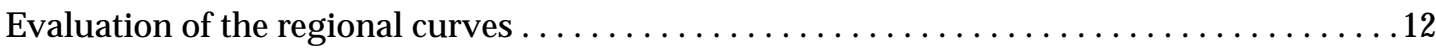

Reference-reach selection. . . . . . . . . . . . . . . . . . . . . . . . . . . . . . . . 14

Comparison of estimates from lowland regional curves and Dunne and Leopold regional

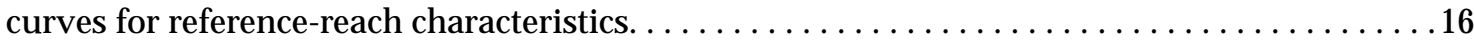

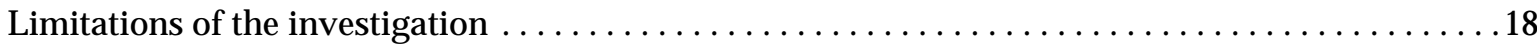

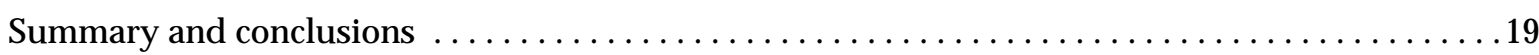

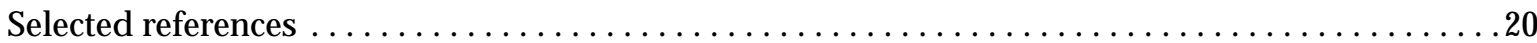

\section{ILLUSTRATIONS}

Figure 1. Map showing locations of the Lowland Sections of the Piedmont

Physiographic Province, project site, reference reach, and streamflowmeasurement stations selected for regional-curve development,

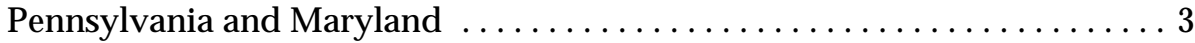

2-7. Photographs showing:

2. View looking upstream at stream reach containing the surveyed cross section for Manatawny Creek near Pottstown, Pennsylvania. . . . . . . 6

3. View looking downstream at stream reach containing both surveyed cross sections for French Creek near Phoenixville, Pennsylvania. . . . 7

4. View looking downstream at stream reach containing one of the two surveyed cross sections for Perkiomen Creek at East Greenville, Pennsylvania................................ 8

5. View looking upstream at stream reach containing both surveyed cross sections at West Branch Perkiomen Creek at Hillegas,

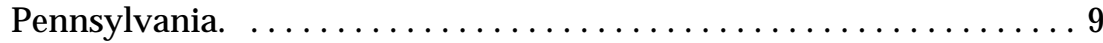

6. View looking downstream at stream reach containing both surveyed cross sections at Sucker Run near Coatesville, Pennsylvania. ...... . 10

7. View looking upstream at stream reach containing the surveyed cross section for Big Pipe Creek at Bruceville, Maryland. ........... 11 


\section{ILLUSTRATIONS-Continued}

Figures 8-11. Graphs showing:

8. Regional curve representing relation between bankfull cross-sectional area and drainage area in non-urban, Lowland Sections of the Piedmont Physiographic Province, Pennsylvania and Maryland.. . . 12

9. Regional curve representing relation between bankfull cross-sectional mean depth and drainage area in non-urban, Lowland Sections of the Piedmont Physiographic Province, Pennsylvania and Maryland..................................... 13

10. Regional curve representing relation between bankfull cross-sectional width and drainage area in non-urban, Lowland Sections of the Piedmont Physiographic Province, Pennsylvania and Maryland.. . . . 13

11. Regional curve representing relation between bankfull discharge and drainage area in non-urban, Lowland Sections of the Piedmont Physiographic Province, Pennsylvania and Maryland. ......... 14

12. Map showing location of project site and reference reach on Bermudian Creek, Adams County, Pennsylvania . . . . . . . . . . . . . . . . . . 15

13. Photograph showing view looking downstream at cross section 526 of the reference reach on Bermudian Creek, Adams County, Pennsylvania .... . 15

\section{TABLES}

Table 1. Data collected during assessment of streamflow-measurement stations used for regional curves in the Lowland Sections of the Piedmont Physiographic Province, Pennsylvania and Maryland ................ 5

2. Cross-section data collected from assessment of reference reach on Bermudian Creek, Adams County, Pennsylvania.................. 17

3. Longitudinal-profile data collected from assessment of reference reach on Bermudian Creek, Adams County, Pennsylvania..................... 18 


\section{CONVERSION FACTORS, VERTICAL DATUM, AND ABBREVIATIONS}

Multiply

foot $(\mathrm{ft})$

mile (mi)

square foot $\left(\mathrm{ft}^{2}\right)$

square mile $\left(\mathrm{mi}^{2}\right)$

cubic foot per second $\left(\mathrm{ft}^{3} / \mathrm{s}\right)$
By

Length

0.3048

1.609

Area

0.09290

2.590

Flow

0.02832
To obtain

meter

kilometer

square meter

square kilometer

cubic meter per second

Vertical datum: In this report, "sea level" refers to the National Geodetic Vertical Datum of 1929-a geodetic datum derived from a general adjustment of the first-order level nets of the United States and Canada, formerly called Sea Level Datum of 1929. 


\section{GLOSSARY}

The terms in this glossary were compiled from numerous sources. Some definitions have been modified for use within this report.

Bankfull channel-The active stream channel during the bankfull discharge.

Bankfull cross-sectional area-The cross-sectional area of the bankfull channel measured perpendicular to the streamflow.

Bankfull discharge-The most effective streamflow for moving sediment, forming or removing bars, forming or changing bends and meanders, and generally doing work that results in the average morphological characteristics of channels (Dunne and Leopold, 1978).

Bankfull mean depth-The mean depth of the bankfull channel measured perpendicular to the streamflow.

Bankfull stage-The elevation of the water surface during bankfull discharge.

Bankfull width-The width of the bankfull channel measured perpendicular to the streamflow.

Belt width-Lateral extent of two sequential meanders measured perpendicular to the valley slope.

D\#\#-The numerical value (\#\#) is the percentage of measured particles within a cross section having an intermediate axis measuring less than a provided dimension.

Drainage area-That area, measured in a horizontal plane, enclosed by a topographic divide from which direct surface runoff from precipitation normally drains by gravity into the stream above the specified point.

Gage height-Water-surface elevation referred to some arbitrary station datum. Gage height commonly is used interchangeably with the more general term "stage."

Reference reach-A reach of stream displaying characteristics of a stable stream channel that is used as a template for design of a stream-restoration project.

Regional curve-A regression of the relations among drainage area, selected cross-sectional parameters, and streamflow.

Regulation-A condition where streamflow is controlled by an upstream man-made feature.

Stream reach-A section of stream extending between 10 and 20 bankfull widths in length.

Stream restoration-For this report, adjusting stream dimensions, pattern, and profile to a condition where it effectively accommodates a range of streamflow and sediment and supports diverse habitat.

Watershed-For this report, used interchangeably with drainage area. 


\title{
Regional Curve Development and Selection of a Reference Reach IN THE NON-URBAN, LOWLAND SECTIONS of the Piedmont Physiographic Province, Pennsylvania and Maryland
}

\author{
By Kirk E. White
}

\begin{abstract}
Stream-restoration projects utilizing naturalstream designs frequently are based on the bankfull-channel characteristics of a stream reach that is accommodating streamflow and sediment transport without excessive erosion or deposition. The bankfull channel is identified by the use of field indicators and confirmed with tools such as regional curves. Channel dimensions were surveyed at six streamflow-measurement stations operated by the U.S. Geological Survey in the Gettysburg-Newark Lowlands Section and Piedmont Lowlands Section of the Piedmont Physiographic Province in Pennsylvania and Maryland. Regional curves were developed from regression analyses of the relation between drainage area and cross-sectional area, mean depth, width, and streamflow of the bankfull channel. Regional curves were used to confirm the identification of the bankfull channel at a reference reach. Stream dimensions and characteristics of the reference reach were measured for extrapolation into the design of a steam-restoration project on Bermudian Creek in Adams County, Pa.
\end{abstract}

Dimensions for cross-sectional area, mean depth, width, and computed streamflow of the bankfull channel in all surveyed riffle cross sections in the reference reach were within the 95-percent confidence interval bounding the regression line representing bankfull channel geometry in the Lowland Sections of the Piedmont Physiographic Province. The average bankfull cross-sectional area, bankfull mean depth, and computed bankfull discharge for riffle cross sections in the reference reach ranged from 15.4 to 16.5 percent less than estimates determined from the lowland regional curves. Average bankfull channel width was about 2 percent greater than estimates. Cross-sectional area, mean depth, and computed streamflow corresponding to the bankfull stage at the reference reach were $31.4,44.4$, and 9.6 percent less, respectively, than estimates derived from the regional curves developed by
Dunne and Leopold in 1978. Average bankfull channel width at the reference reach was 16.7 percent greater than the Dunne and Leopold estimate.

The concepts of regional curves and reference reaches can be valuable tools to support efforts in stream restoration. Practitioners of stream restoration need to recognize them as such and realize their limitations. The small number of stations available for analysis is a major limiting factor in the strength of the results of this investigation. Subjective selection criteria may have unnecessarily eliminated streamflow-measurement stations that could have been included in the regional curves. A bankfull discharge with a recurrence interval within the 1- to 2-year range was used as a criteria for confirmation of the bankfull stage at each streamflow-measurement station. Many researchers accept this range for recurrence interval of the bankfull discharge; however, literature provides contradictory evidence. The use of channel-characteristics data from a reference reach without any monitoring data to document the stability of the reference reach over time is a topic of debate.

\section{INTRODUCTION}

Restoration projects of stream channels with excessive erosion, deposition, or degraded habitat are being proposed by Federal, state, local, and private organizations in an effort to return the impaired streams to more stable and biologically productive conditions. Traditional engineering practices for stream stabilization frequently rely on hardening the sections of a stream impacted by erosive forces. Recent restoration projects propose to utilize a natural stream design approach that emphasizes working in concert with natural stream processes as opposed to combating them.

Accelerated bank erosion in a section of Bermudian Creek, Adams County, Pa., is endangering some structures that border the creek and may impair present habitat. This reach of Bermudian 
Creek has been identified for streambank stabilization utilizing natural stream design. The restoration project will be designed by the Pennsylvania Department of Environmental Protection (PaDEP), Bureau of Waterways Engineering, to accommodate the bankfull discharge ${ }^{1}$ for this segment of Bermudian Creek.

The bankfull discharge is considered to be the most effective streamflow for moving sediment, forming or removing bars, forming or changing bends and meanders, and generally doing work that results in the average morphological characteristics of channels (Dunne and Leopold, 1978). Bankfull discharge occurs 1 or 2 days each year with an average recurrence interval of 1.5 years (Leopold, 1994).

As the basis of the restoration design, the bankfull channel is defined and verified by field reconnaissance and direct measurement of channel features. In addition to identifying the bankfull channel on the basis of field indicators, an independent source of information that supports the identification is needed.

Some of the more common tools available for supporting the selection of the bankfull channel are regional curves. One set of regional curves developed by Dunne and Leopold (1978) was intended to be representative of bankfull-channel dimensions throughout the eastern United States. The applicability of one set of regional curves to the multiple physiographic provinces and/or geology throughout Pennsylvania has not been verified.

Dimensions of the bankfull channel are defined by characteristics such as cross-sectional area, width, and mean depth. These characteristics are highly correlated with drainage area (Dunne and Leopold, 1978). Regional curves are developed by regression analysis and provide estimated bankfull-channel dimensions when drainage area is known. Estimates of bankfull dimensions are helpful for confirming field identification of the bankfull channel.

PaDEP will develop a restoration design on the basis of stream-channel measurements made at a stream reach having similar runoff characteristics to those of the proposed restoration site. The stream reference reach must appear stable, for

\footnotetext{
${ }^{1}$ Words presented in bold type are defined in the Glossary section of this report.
}

example, capable of effectively accommodating streamflow and sediment without excessive channel erosion or deposition. A comprehensive site assessment of a reference reach will quantify numerous bankfull-channel characteristics of an apparently stable form from which to simulate the morphology of restored channel.

In 1999, PaDEP proposed a study to develop regional curves representative of channel geometry in the Piedmont Physiographic Province and to quantify channel characteristics of a stream reach for use as a template in a stream-restoration design. PaDEP and the U.S. Geological Survey (USGS) conducted this study as a cooperative effort.

\section{Purpose and Scope}

This report describes the methods used, data collected, the results of regional-curve development, and the selection of a reference reach. Regional curves developed from channel-characteristics data collected from December 1999 to March 2000 that represent channel dimensions in the Piedmont Lowland and Gettysburg-Newark Lowland Sections of the Piedmont Physiographic Province within Pennsylvania and Maryland are presented. Channel characteristics of a reference reach on Bermudian Creek in the Gettysburg-Newark Lowland Section in Adams County, Pa., also are presented.

\section{Description of Study Area}

The Piedmont Physiographic Province is separated into three sections: Piedmont Upland Section, Piedmont Lowland Section, and the Gettysburg-Newark Lowland Section. This investigation is restricted to streamflow-measurement stations in the two lowland sections. Major locations and their physiographic contexts related to this investigation are shown in figure 1.

The Piedmont Lowland Section study area in Pennsylvania consists of broad, moderately dissected valleys separated by broad low hills. The Section is developed primarily on limestone and dolomite rock. Karst topography is common. Local relief in the Section generally is less than $100 \mathrm{ft}$ but may be as much as $300 \mathrm{ft}$. Land-surface elevations in the Section range from 170 to $630 \mathrm{ft}$. Drainage is basically dendritic in pattern, but some areas have virtually no pattern because of the well-developed subsurface drainage (Sevon, 2000). 

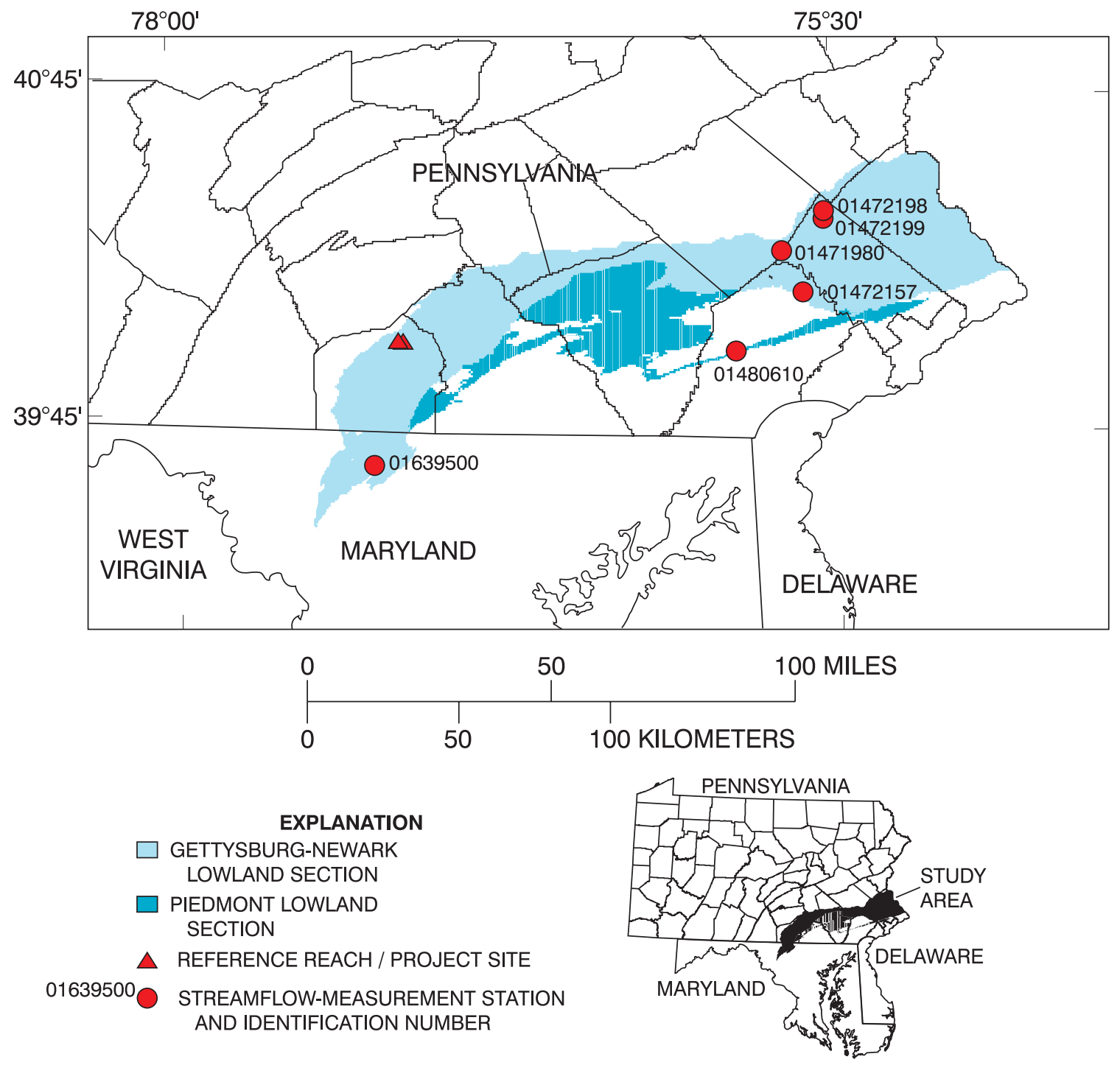

Figure 1. Locations of the Lowland Sections of the Piedmont Physiographic Province, project site, reference reach, and streamflow-measurement stations selected for regional-curve development, Pennsylvania and Maryland. (Physiographic Provinces from Sevon, 2000.)

The Gettysburg-Newark Lowland Section study area in Pennsylvania and Maryland consists mainly of rolling low hills and valleys developed on red sedimentary rock. Isolated higher hills developed on diabase, baked sedimentary rock, and conglomerates. Almost all the underlying sedimentary rock dips to the north or northwest, and many smaller drainageways are oriented normal to the direction of dip so that some topography has a northeast-southwest linearity. The basic drainage pattern is dendritic. Relief generally is in the area of 100 to $200 \mathrm{ft}$ but locally is up to $600 \mathrm{ft}$ on some of the isolated hills. Elevation in the Section ranges from 40 to 1,335 ft (Sevon, 2000). 


\section{STUDY DESIGN}

Only streamflow-measurement stations in the Lowland Sections of the Piedmont Physiographic Province (Sevon, 2000) were included in developing these regional curves. Streamflowmeasurement stations in the Upland Section of the Piedmont are omitted from this initial regional relation because of potentially major differences in runoff characteristics between the Upland and Lowland Sections. Subjective filtering criteria utilizing Geographic Information System land-use (U.S. Geological Survey, 1996) and stream coverages (Pennsylvania Department of Transportation, 1997; Alexander and others, 1999) and additional station-information criteria were used to identify streamflow-measurement stations with similar runoff characteristics. The distribution of watershed size, upstream from the selected stations, needed to be large enough to provide confidence in the relation over a range of drainage areas. The filtering criteria used for selecting streamflow-measurement stations are listed below.

- The station is within the boundaries of a Lowland Section of the Piedmont Physiographic Province.

- The station has at least 10 years of record.

- The period of record for the station extends at least to 1985 to minimize the extent to which changes in land use may have affected the channel since the station was active.

- No more than 20 percent of the upstream watershed is classified as urban land use.

- Streamflow at the station is subjected to no greater than 20 percent regulation.

The filtering criteria were applied to a comprehensive listing of current and historical continuous- and partial-record stations operated by the USGS in Pennsylvania and Maryland. Stations meeting all criteria were considered for inclusion in the investigation. Station descriptions describing flow conditions and site characteristics are on file in USGS offices, and in some instances, field reconnaissance was used to finalize the list of stations included in the formulation of the regional curves. On the basis of the filtering criteria, six streamflow-measurement stations were selected for inclusion in the regional-curve development.

Procedures for field assessments, outlined by Leopold (1994) and Rosgen (1996), were followed for the data collection at each station. Deviations from the established procedure, warranted because of site conditions, are discussed along with the specific details describing each streamflow-measurement station. Surveyed elevations are recorded to the hundredth of a foot. Stream slopes calculated from survey data are presented to the thousandth of a foot to provide the user with relative differences between stream slopes and sufficient data for rounding purposes.

Field reconnaissance was conducted to locate a reference reach that could serve as a template for the restoration design. Qualitative criteria were developed to identify a stream reach that appeared to effectively accommodate streamflow and sediment transport without excessive channel erosion or deposition. The criteria used to identify the reference reach are as follows.

- Runoff characteristics are similar to those of the restoration project site.

- Channel width and depth within the reach do not change dramatically.

- Rapidly eroding banks or areas of excessive deposition are not evident.

- Riffles are characterized by an appropriate degree of embeddedness.

- Accumulation of debris is not excessive.

The selection criteria were applied to stream segments in Bermudian Creek and elsewhere in the vicinity of the restoration project site. A 1,000-ft reach of Bermudian Creek upstream from the project site met the criteria and was selected. Field procedures for characterizing a reference reach, outlined by Harrelson and others (1994) and Rosgen (1996), were followed for the assessment of the reference reach on Bermudian Creek. 


\section{REGIONAL-CURVE DEVELOPMENT}

Because many restoration designs are dependent on bankfull-channel dimensions, correctly identifying the bankfull stage is essential to a successful design. According to Dunne and Leopold (1978), the width, mean depth, and cross-sectional area of the bankfull channel are highly correlated with the size of the basin (drainage area) in a given region. Familiarity with these regional relations is useful for field identification of the bankfull channel. A regional curve is a regression of these relations and provides estimated channel dimensions and streamflow for the bankfull channel when drainage area is known.

USGS streamflow-measurement stations provide a source of readily available and reliable information from which regional curves can be developed. The drainage area has been accurately determined for each station. Streamflow measurements provide a long-term record of channel dimensions over a broad range of streamflows. Peak-flow analysis of station record provides the frequencies of occurrence for a range of streamflows. By identifying the bankfull stage at a streamflow-measurement station, the investigator can determine if the associated streamflow is within the 1- to 2-year recurrence-interval range.
Once confirmed, the bankfull channel is surveyed at riffle cross sections and the cross-sectional dimensions are determined. Plotting the bankfullchannel dimensions and streamflow for each streamflow-measurement station in relation to its drainage area provides the data necessary for defining the relation. A "best-fit" regression line is applied to the data to form the regional curve. Use of the USGS streamflow-measurement data does not necessarily provide absolute confirmation of the bankfull discharge but does support the identification of the bankfull channel when used along with other field indicators. Once developed, investigators can use regional curves at unmonitored sites to support or refute their identification of the bankfull channel within regions having similar runoff characteristics.

Applying the previously described filtering criteria to USGS streamflow-measurement stations identified six stations in the Lowland Sections of the Piedmont Physiographic Province. Characteristics of each streamflow-measurement station included in the investigation are discussed below. Other data directly relating to the site assessments are included in table 1. Rosgen (1996) stream type refers to a stream classification based on the morphological characteristics of a stream reach.

Table 1. Data collected during assessment of streamflow-measurement stations used for regional curves in the Lowland Sections of the Piedmont Physiographic Province, Pennsylvania and Maryland

[WY, water year ${ }^{1} ; \mathrm{mi}^{2}$, square miles; $\mathrm{ft}$, feet; $\mathrm{ft}^{2}$, square feet; $\mathrm{ft}^{3} / \mathrm{s}$, cubic feet per second; $\mathrm{ft} / \mathrm{ft}$, feet per foot; GNL, Gettysburg-Newark Lowland Section; PL, Piedmont Lowland Section]

\begin{tabular}{|c|c|c|c|c|c|c|c|c|c|c|c|}
\hline $\begin{array}{c}\text { U.S. } \\
\text { Geological } \\
\text { Survey } \\
\text { station } \\
\text { identification } \\
\text { number } \\
\text { (see fig. 1) }\end{array}$ & $\begin{array}{l}\text { Period of } \\
\text { record } \\
(\mathrm{WY})\end{array}$ & $\begin{array}{l}\text { Physio- } \\
\text { graphic } \\
\text { section }\end{array}$ & $\begin{array}{l}\text { Rosgen } \\
\text { stream } \\
\text { type }^{2}\end{array}$ & $\begin{array}{c}\text { Drainage } \\
\text { area } \\
\left(\mathrm{mi}^{2}\right)\end{array}$ & $\begin{array}{l}\text { Bankfull } \\
\text { cross- } \\
\text { sectional } \\
\text { area } \\
\left(\mathrm{ft}^{2}\right)\end{array}$ & $\begin{array}{l}\text { Bankfull } \\
\text { width } \\
(\mathrm{ft})\end{array}$ & $\begin{array}{l}\text { Bankfull } \\
\text { mean } \\
\text { depth } \\
(\mathrm{ft})\end{array}$ & $\begin{array}{c}\text { Estimated } \\
\text { bankfull } \\
\text { stage } \\
\text { (ft) }\end{array}$ & $\begin{array}{c}\text { Estimated } \\
\text { bankfull } \\
\text { discharge } \\
\left(\mathrm{ft}^{3} / \mathrm{s}\right)\end{array}$ & $\begin{array}{c}\text { Recurrence } \\
\text { interval } \\
\text { (years) }\end{array}$ & $\begin{array}{c}\text { Slope } \\
\text { (ft/ft) }\end{array}$ \\
\hline 01471980 & $1974-2000$ & GNL & $\mathrm{C} 4$ & 85.5 & 468 & 90.1 & 5.19 & 6.26 & 2,340 & 1.3 & ${ }^{3} 0.001$ \\
\hline 01472157 & 1969-2000 & GNL & $\mathrm{C} 3$ & 59.1 & 316 & 87.1 & 3.63 & 7.78 & 1,440 & 1.3 & .004 \\
\hline 01472198 & $1982-2000$ & GNL & $\mathrm{C} 4$ & 38.0 & 304 & 117 & 2.65 & 3.83 & 1,190 & 1.4 & .002 \\
\hline 01472199 & $1982-2000$ & GNL & $\mathrm{C} 4$ & 23.0 & 202 & 96.5 & 1.94 & 4.79 & 1,000 & 1.5 & .004 \\
\hline 01480610 & $1964-2000$ & $\mathrm{PL}$ & B5c & 2.57 & 24.0 & 17.8 & 1.36 & 4.83 & 143 & 1.2 & .009 \\
\hline 01639500 & 1948-2000 & GNL & $\mathrm{C} 4$ & 102 & 616 & 101 & 6.12 & 7.93 & 3,060 & 1.5 & .001 \\
\hline
\end{tabular}

\footnotetext{
${ }^{1}$ The 12-month period October 1 through September 30 designated by the calendar year in which it ends.

${ }^{2}$ Rosgen, 1996.

${ }^{3}$ Slope not computed from entire reach.
} 
Description of Streamflow-Measurement Stations

USGS Station Number: 01471980

Stream Name: Manatawny Creek

Location: near Pottstown, Pennsylvania (Lat $40^{\circ} 16^{\prime} 22^{\prime \prime}$, Long $75^{\circ} 40^{\prime} 49^{\prime \prime}$ )

The streamflow-measurement station on Manatawny Creek monitors streamflow from an $85.5-\mathrm{mi}^{2}$ watershed, less than 2 percent of which is classified as urban land use (U.S. Geological Survey, 1996). Streamflow upstream from the station is not regulated, 26 percent of the watershed is underlain by carbonate geology, and 56 percent is covered by forest. Only about 15 percent of the Manatawny Creek watershed upstream from the station is in the Gettysburg-Newark Lowland Section of the Piedmont Physiographic Province (Pennsylvania Department of Transportation, 1997; Sevon, 2000). The remainder is in the Great Valley Section of the Ridge and Valley Physiographic Province (45 percent) and the Reading Prong Section of the New England Physiographic Province (40 percent). Manatawny Creek near Pottstown is a continuous streamflow-measurement station about $180 \mathrm{ft}$ upstream from a bridge. The bridge does not appear to constrict the bankfull discharge. Streamflow-measurement data stored in the USGS hydrologic data base indicate wading measurements at this station are usually made in the approximate location of the cross-section survey. High-water measurements are made from the bridge.

The bankfull channel clearly was defined throughout most of the reach by field indicators such as riparian vegetation and depositional features. The cross-section survey was limited to one cross section conducted in a "run" (an area of intermediate relative velocity) because of the presence of a divided channel throughout the upstream half of the reach. Two riffles were eliminated from consideration because of their proximity to the divided channel. One riffle was within the divided channel section, and channel geometry was strongly affected. The other riffle was at the confluence of the two flow paths and was still in transition to a single flow path. The stream reach containing the surveyed cross section is shown in figure 2. A pebble count was conducted within the cross section to determine the distribution of particle sizes on the streambed. The elevation of the bankfull stage was surveyed to the outside vertical staff gage from which the gage height and associated bankfull discharge were determined. The channel geometry at the estimated bankfull discharge, as indicated by streamflow-measurement data in the USGS database, was used to assist with confirmation of bankfull selection.

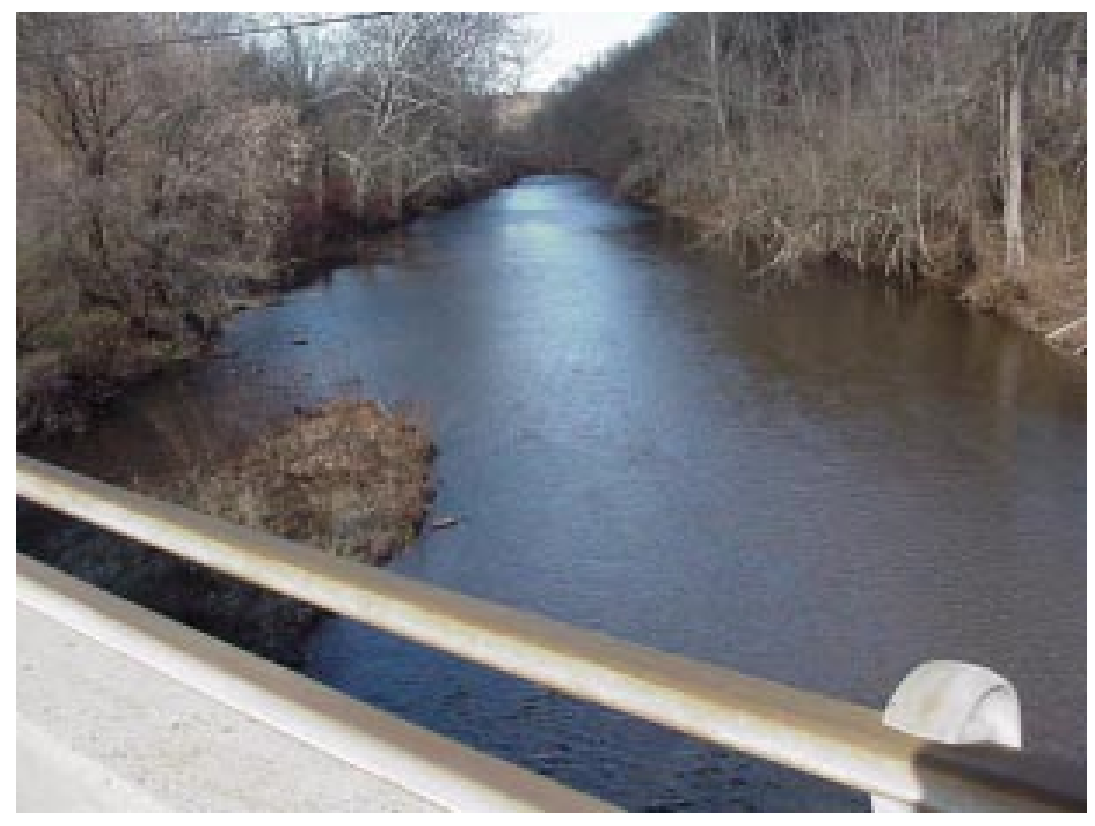

Figure 2. View looking upstream at stream reach containing the surveyed cross section for Manatawny Creek near Pottstown, Pennsylvania. 
USGS Station Number: 01472157

Stream Name: French Creek

Location: near Phoenixville, Pennsylvania (Lat $40^{\circ} 09^{\prime} 05^{\prime \prime}$, Long $75^{\circ} 36^{\prime} 06^{\prime \prime}$ )

The streamflow-measurement station on French Creek monitors streamflow from a $59.1-\mathrm{mi}^{2}$ watershed, less than 1 percent of which is classified as urban land use (U.S. Geological Survey, 1996). About 2 percent of the watershed upstream from the station is regulated, carbonate geology is not present within the watershed, and 64 percent of the watershed is covered by forest. About 38 percent of the French Creek watershed upstream from the station is in the Gettysburg-Newark Lowland Section of the Piedmont Physiographic Province (Pennsylvania Department of Transportation, 1997; Sevon, 2000). The remainder is in the Piedmont Uplands. French Creek near Phoenixville is a continuous streamflow-measurement station about $70 \mathrm{ft}$ downstream from a bridge. The bridge may have a slight effect on the bankfull discharge. Streamflow-measurement data stored in the USGS hydrologic data base indicate wading measurements usually are made in the vicinity of the station. High-water measurements are made from the bridge.
The bankfull channel, in the vicinity of the streamflow-measurement station, was poorly defined because of excessive bank erosion. Directly across from the streamflow-measurement shelter is an auxiliary channel, separated from the main channel by a berm that extends $500 \mathrm{ft}$ downstream. This auxiliary channel is a component of the bankfull channel and contains flowing water during moderate streamflow. Riffles within this area were not surveyed because of the resulting divided channel at the bankfull discharge. Excellent bankfull indicators were identified on a point bar beginning about $700 \mathrm{ft}$ downstream from the station. Two cross sections were surveyed at riffles within the reach, and pebble counts were conducted within each to determine the particle distribution. The stream reach containing both surveyed cross sections is shown in figure 3 . The bankfull widths, mean depths, and cross-sectional areas of the two cross sections were averaged to determine the input for the regional curves. The bankfull elevation was extended upstream to the streamflowmeasurement station, with some difficulty, to determine the gage height and streamflow associated with the bankfull stage. The channel geometry at the estimated bankfull discharge, as indicated by streamflow-measurement data in the USGS data base, was used to assist with confirmation of the bankfull selection.

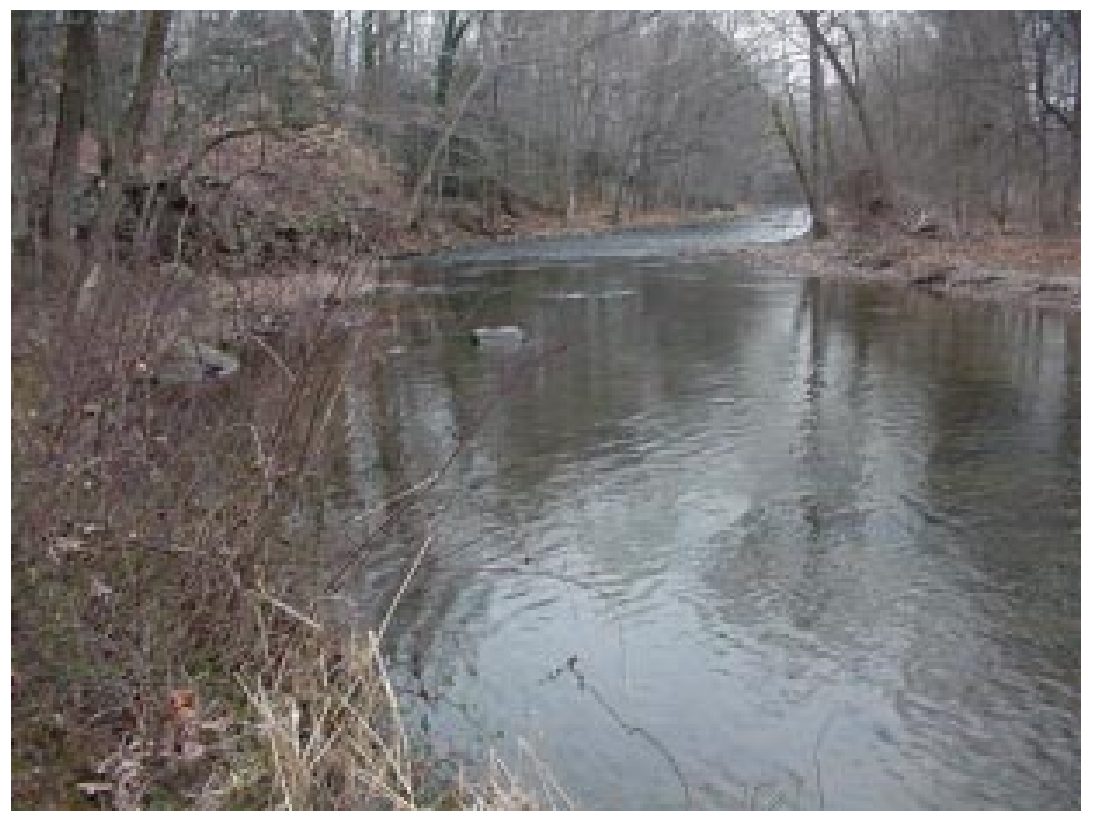

Figure 3. View looking downstream at stream reach containing both surveyed cross sections for French Creek near Phoenixville, Pennsylvania. 
USGS Station Number: 01472198

Stream Name: Perkiomen Creek

Location: at East Greenville, Pennsylvania

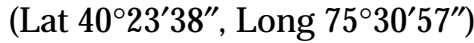

The streamflow-measurement station on Perkiomen Creek monitors streamflow from a $38.0-\mathrm{mi}^{2}$ watershed, 2 percent of which has urban land use (U.S. Geological Survey, 1996). Streamflow upstream from the station is not regulated, 3 percent of the watershed is underlain by carbonate geology, and 54 percent is covered by forest. About 51 percent of the Perkiomen Creek watershed, upstream from the station, is in the Gettysburg-Newark Lowland Section of the Piedmont Physiographic Province (Pennsylvania Department of Transportation, 1997; Sevon, 2000). The remainder is in the Reading Prong Section of the New England Physiographic Province (40 percent) and the Great Valley Section of the Ridge and Valley Physiographic Province (9 percent). Perkiomen Creek at East Greenville is a continuous streamflow-measurement station adjacent to a pool created by a weir immediately downstream from the shelter. A multi-span bridge is $100 \mathrm{ft}$ downstream from the weir and does not appear to constrict the bankfull discharge. Wading streamflow measurements usually are made downstream from the weir and the bridge. High-water measurements are made from the bridge.

The bankfull channel in the assessed reach was fairly well defined. Two cross sections were surveyed at riffles within the reach, and pebble counts were conducted within each to determine the particle distribution. A section of the stream reach previously was stabilized; however, cross sections were beyond the affected stream section. The stream reach containing the upstream surveyed cross section is shown in figure 4 . The bankfull widths, mean depths, and cross-sectional areas of the two cross sections were averaged to determine the input for the regional curves. The bankfull water-surface elevation could not be extended upstream to the streamflow-measurement station because of the relatively high-profile weir. The channel geometry at the estimated bankfull discharge, as indicated by streamflow-measurement data stored in the USGS data base, was used to assist with confirmation of the bankfull selection.

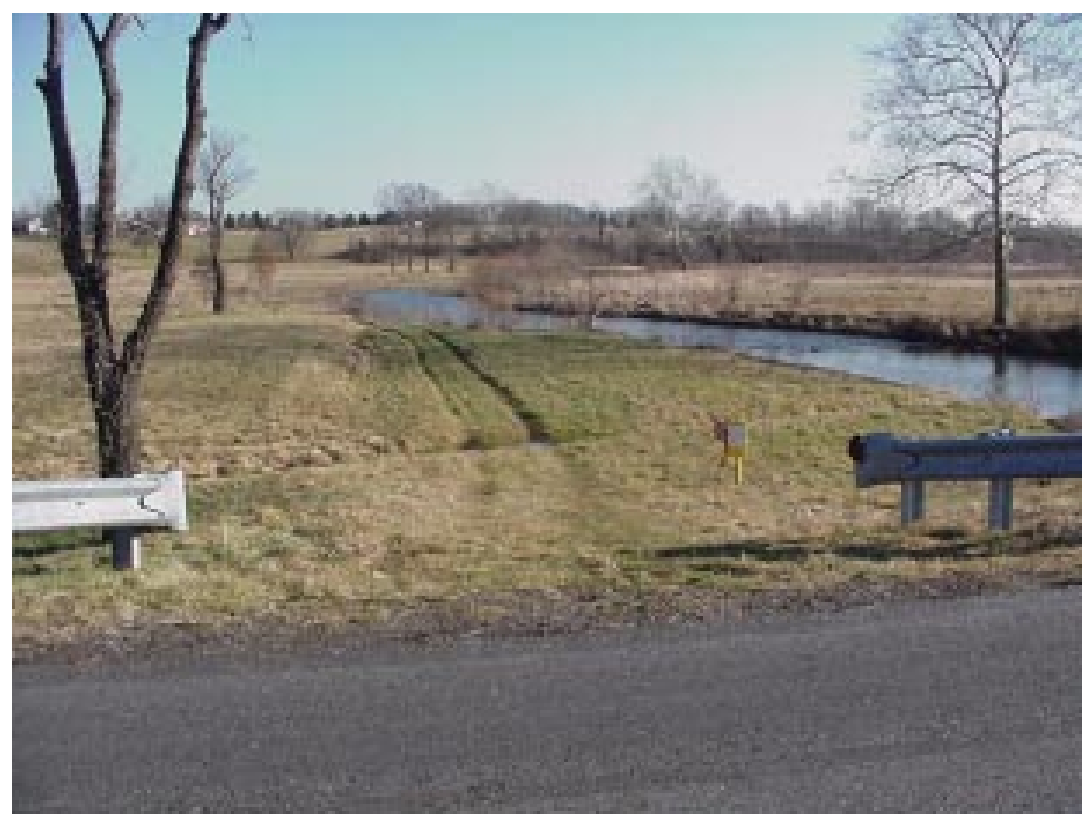

Figure 4. View looking downstream at stream reach containing one of the two surveyed cross sections for Perkiomen Creek at East Greenville, Pennsylvania. 
USGS Station Number: 01472199

Stream Name: West Branch Perkiomen Creek Location: at Hillegas, Pennsylvania

(Lat $40^{\circ} 22^{\prime} 26^{\prime \prime}$, Long $75^{\circ} 31^{\prime} 22^{\prime \prime}$ )

The streamflow-measurement station on the West Branch of Perkiomen Creek monitors streamflow from a 23.0- $\mathrm{mi}^{2}$ watershed, 2 percent of which is classified as urban land use (U.S. Geological Survey, 1996). Streamflow is not regulated above the station, 4 percent of the watershed is underlain by carbonate geology, and 61 percent is covered by forest. About 43 percent of the watershed upstream from the station is in the Gettysburg-Newark Lowland Section of the Piedmont Physiographic Province (Pennsylvania Department of Transportation, 1997; Sevon, 2000). The remainder of the watershed is in the Reading Prong Section of the New England Physiographic Province (50 percent) and the Great Valley Section of the Ridge and Valley Physiographic Province (7 percent). West Branch Perkiomen Creek at Hillegas is a continuous streamflow-measurement station adjacent to a pool created by a weir immediately downstream from the shelter. The rating is considered to be poorly defined above $560 \mathrm{ft}^{3} / \mathrm{s}$ because of the lack of a good location from which to make high-water measurements. Wading streamflow measurements are conducted throughout the stream reach both upstream and downstream from the weir.

The assessed reach was separated from the pool behind the weir by a high-profile rock outcrop. The bankfull channel clearly was defined throughout most of the assessed reach. Two cross sections were surveyed at riffles within the assessed reach, and pebble counts were conducted within each to determine the particle distribution. The stream reach containing both surveyed cross sections is shown in figure 5 . The bankfull widths, mean depths, and cross-sectional areas of the two cross sections were averaged to determine the input for the regional curves. Despite the presence of the rock outcrop, the bankfull elevation could be extended to the outside vertical staff gage adjacent to the streamflow-measurement station, with reasonable certainty, to determine the gage height and streamflow associated with the bankfull stage. The channel geometry at the estimated bankfull discharge, as indicated by measurement data in the USGS database, was used to assist with confirmation of the bankfull selection.

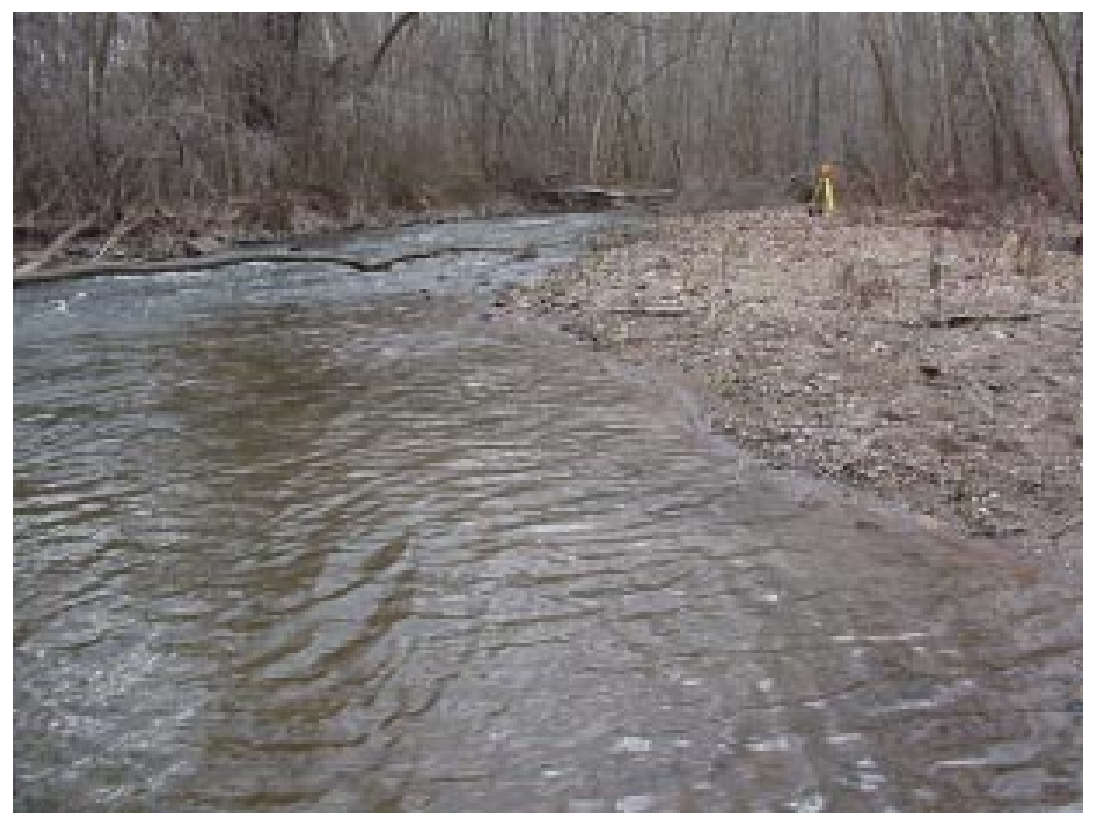

Figure 5. View looking upstream at stream reach containing both surveyed cross sections at West Branch Perkiomen Creek at Hillegas, Pennsylvania. 
USGS Station Number: 01480610

Stream Name: Sucker Run

Location: near Coatesville, Pennsylvania (Lat 39 $58^{\prime} 20^{\prime \prime}$, Long 75 $51^{\prime} 03^{\prime \prime}$ )

The streamflow-measurement station on Sucker Run monitors streamflow from a $2.57-\mathrm{mi}^{2}$ watershed, 11.6 percent of which is classified as urban land use (U.S. Geological Survey, 1996). Streamflow is not regulated above the station, 35.7 percent of the watershed is underlain by carbonate geology, and about 45 percent is covered by forest. Just over half of the Sucker Run watershed (53 percent) upstream from the station is in the Piedmont Lowland Section of the Piedmont Physiographic Province. (Pennsylvania Department of Transportation, 1997; Sevon, 2000). The remainder of the watershed is in the Piedmont Upland Section. Two bridges, which are $227 \mathrm{ft}$ apart, bound the reach and may slightly constrict the bankfull discharge. Sucker Run near Coatesville is a creststage, partial-record station that does not collect continuous data but is operated primarily to document peak streamflow. Wading streamflow mea- surements usually are made throughout the section of stream in which the cross-section surveys were conducted. High-water measurements are made from the bridge immediately upstream from the station.

Definition of the bankfull channel, in the vicinity of the streamflow-measurement station, was fair. Two cross sections were surveyed at riffles within the reach, and pebble counts were conducted within each to determine the particle distribution. The stream reach containing both surveyed cross sections is shown in figure 6 . The bankfull widths, mean depths, and cross-sectional areas of the two cross sections were averaged to determine the input for the regional curves. The bankfull water-surface elevation was extrapolated to the outside vertical staff gage, with reasonable certainty, to determine the gage height and streamflow associated with the bankfull stage. The channel geometry at the estimated bankfull discharge, as indicated by streamflow-measurement data in the USGS data base, was used to assist with confirmation of the bankfull selection.

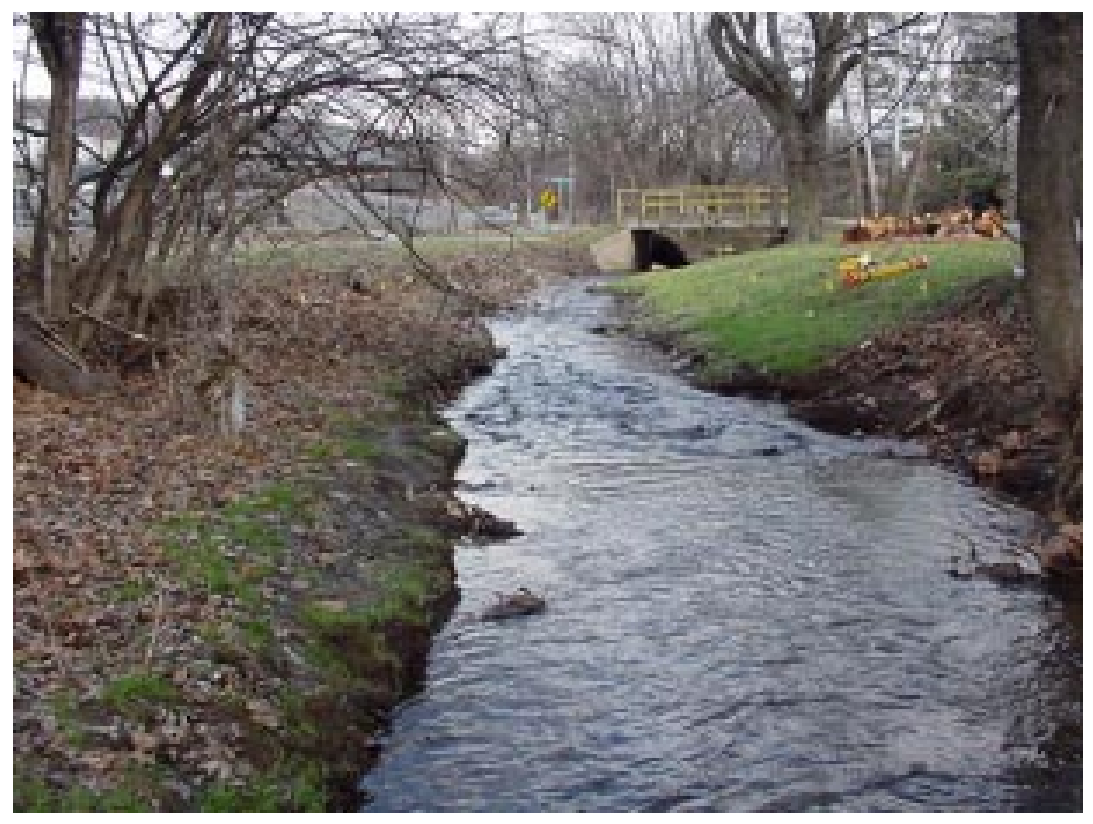

Figure 6. View looking downstream at stream reach containing both surveyed cross sections at Sucker Run near Coatesville, Pennsylvania. 
USGS Station Number: 01639500

Stream Name: Big Pipe Creek

Location: at Bruceville, Maryland

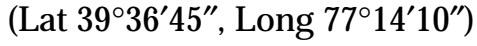

The streamflow-measurement station on Big Pipe Creek monitors streamflow from a 102- $\mathrm{mi}^{2}$ watershed. Limited quantitative data describing land use in the watershed are available. There is little or no effect from urban land use, regulation has no appreciable effect on streamflow, there is no apparent carbonate geology, and about 17 percent of the watershed upstream from the station is covered by forest (R.W. James, Jr., U.S. Geological Survey, oral commun., 2001). About 32 percent of the Big Pipe watershed upstream from the station is in the Gettysburg-Newark Lowland Section of the Piedmont Physiographic Province; the remainder is in the Piedmont Upland Section. Big Pipe Creek at Bruceville is a continuous streamflow-measurement station adjacent to a pool created by a lowprofile weir $25 \mathrm{ft}$ downstream from the shelter. A multi-span bridge is $300 \mathrm{ft}$ upstream from the station and does not appear to constrict the bankfull discharge. Wading streamflow measurements usually are made upstream from the station. Highwater measurements are made from the bridge.
The site assessment was limited to one crosssection survey within the reach because of a storm event and resulting elevated streamflow midway through the assessment. The stream reach containing the surveyed cross section is shown in figure 7. A pebble count was conducted within the cross section to determine the particle distribution. The bankfull channel clearly was defined throughout most of the reach with the exception of within the bridge right-of-way. The bankfull water-surface elevation passed the outside vertical staff gage from which the gage height and streamflow associated with the bankfull stage were determined. The channel geometry at the estimated bankfull discharge, as indicated by measurement data in the USGS database, was used to assist with confirmation of the bankfull selection.

Field evidence suggested by researchers (Dunne and Leopold, 1978, Rosgen, 1996, Harrelson and others, 1994) as being indicative of the bankfull channel was used at each station in the initial identification of the bankfull channel. Stations where a clearly defined bankfull stage elevation passed through (for example, Manatawny Creek near Pottstown and Big Pipe Creek at Bruceville), or was extrapolated to (for example,

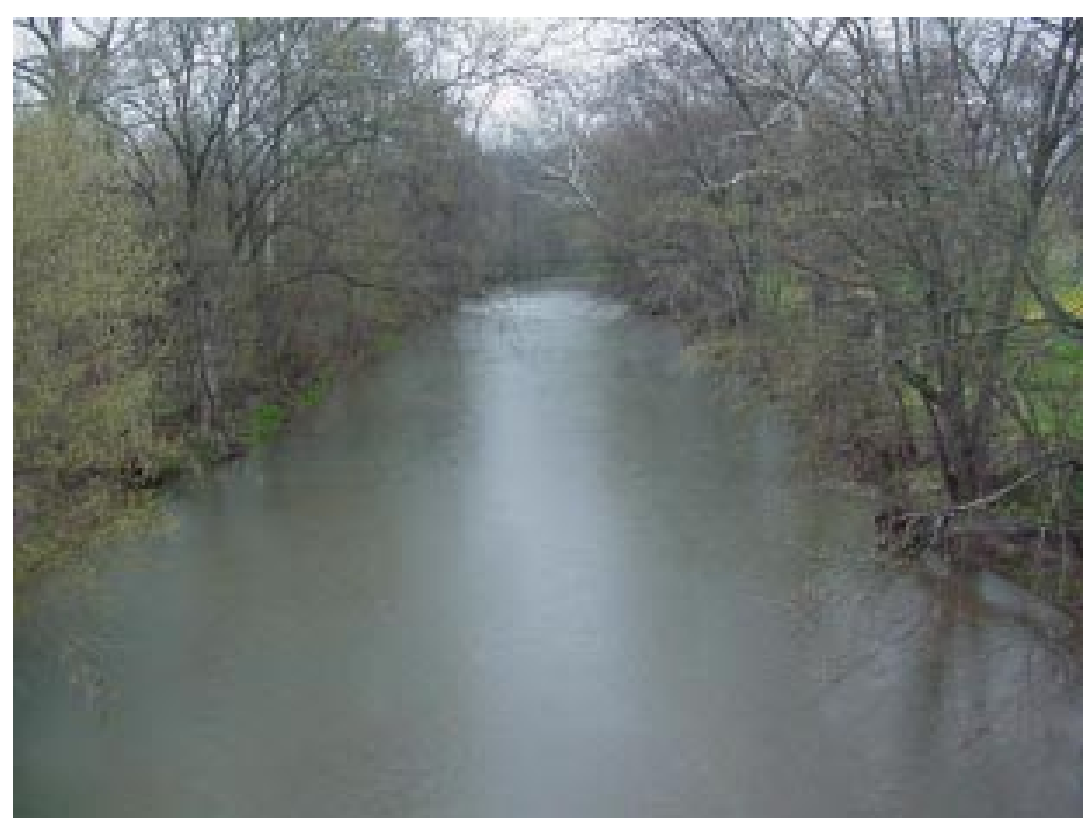

Figure 7. View looking upstream at stream reach containing the surveyed cross section for Big Pipe Creek at Bruceville, Maryland. 
Sucker Run near Coatesville and West Branch Perkiomen Creek at Hillegas), the outside vertical staff gage with reasonable certainty provided the most confidence for the bankfull determination. Stations where the bankfull stage was not clearly defined in the vicinity of the streamflow-measurement station (for example, French Creek near Phoenixville) required more emphasis on additional data for confirmation. Perkiomen Creek at East Greenville, with fair definition of the bankfull channel but no opportunity for comparison of bankfull stage to the outside vertical staff gage, required the most reliance on additional data for confirmation of bankfull identification. Channel geometry as indicated from streamflow measurements made at the station, streamflow computed from cross-section characteristics, and determination of the sediment size being transported during the bankfull discharge were used to assist with confirmation of bankfull channel dimensions at all stations.

\section{Evaluation of the Regional Curves}

The regional curves presented in figures 8 through 11 show the relation between drainage area and bankfull cross-sectional area, bankfull mean depth, bankfull width, and bankfull dis- charge, respectively. The 95-percent confidence interval indicates a band within which there is a 95-percent probability that estimates of channel geometry and streamflow for that particular drainage area will occur. The coefficient of determination, $R^{2}$, is a measure of the variability in the channel-geometry estimate accounted for by the drainage area. Bankfull cross-sectional area (fig. 8) and bankfull discharge (fig. 11) have the strongest relation to drainage area as evidenced by $R^{2}$ values of 0.98 . Both relations have a p-value less than 0.001 , a residual standard error of 0.07 or less, and a $\mathrm{t}$-value for the drainage-area coefficient between 15.8 and 16.4. Users of these two regional curves would expect to obtain the most reliable estimates. The relation between bankfull mean depth and drainage area (fig. 9) with an $\mathrm{R}^{2}$ of 0.84 and a $\mathrm{p}$-value less than 0.01 (residual standard error $=0.11$ and a $\mathrm{t}$-value $=4.6$ ) indicates a very strong linear trend between all the stations except the one with the smallest drainage area. The relation between bankfull width and drainage area (fig. 10) is the weakest of the four- $\mathrm{R}^{2}$ value of 0.79 , p-value less than 0.02 , a residual standard error of 0.16 , and a $t$-value for the drainage area coefficient of 3.9 .

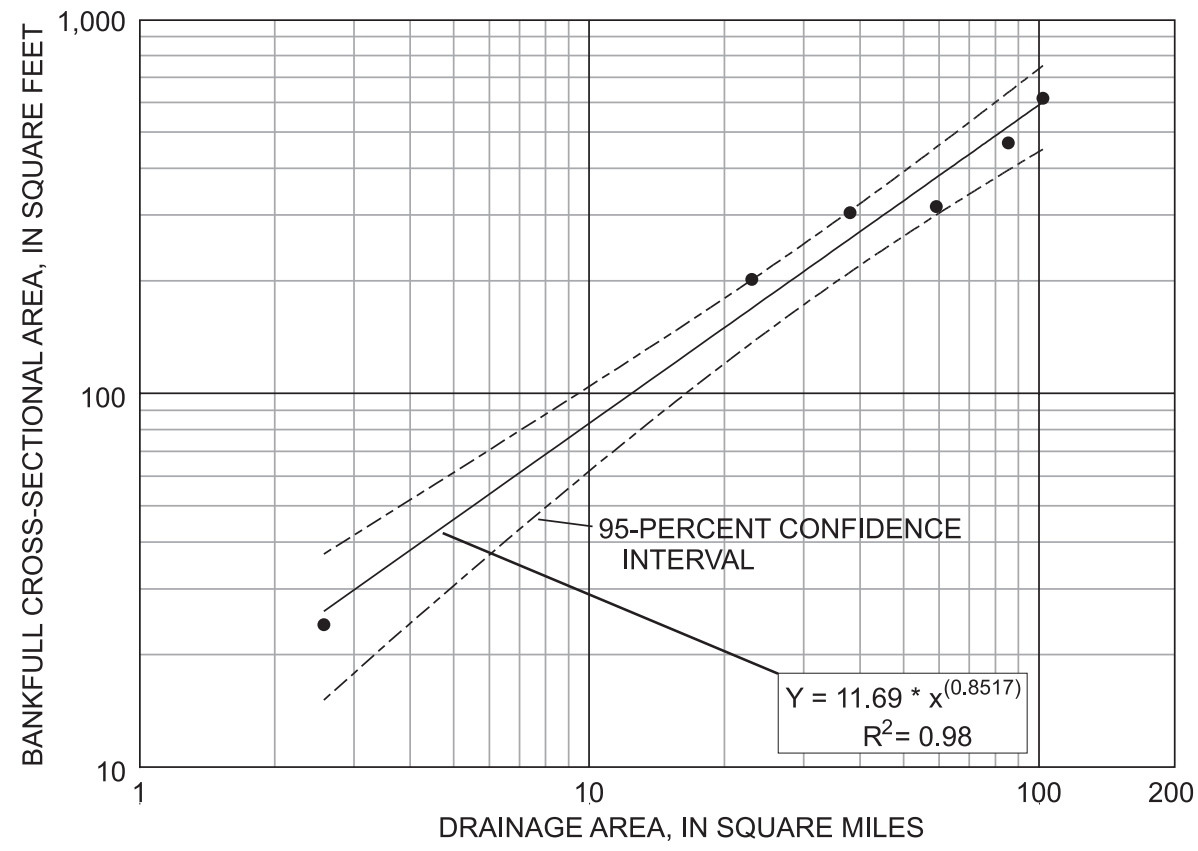

Figure 8. Regional curve representing relation between bankfull cross-sectional area and drainage area in non-urban, Lowland Sections of the Piedmont Physiographic Province, Pennsylvania and Maryland. 


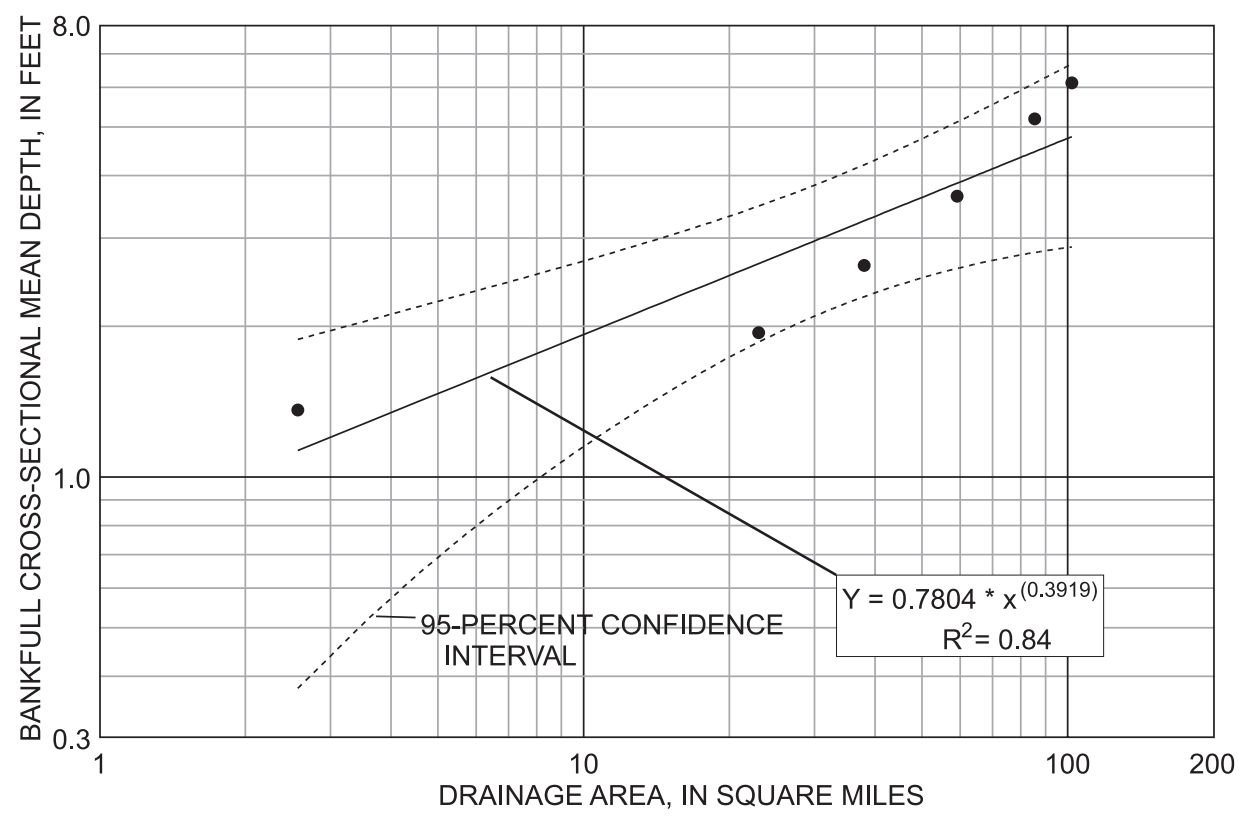

Figure 9. Regional curve representing relation between bankfull cross-sectional mean depth and drainage area in non-urban, Lowland Sections of the Piedmont Physiographic Province, Pennsylvania and Maryland.

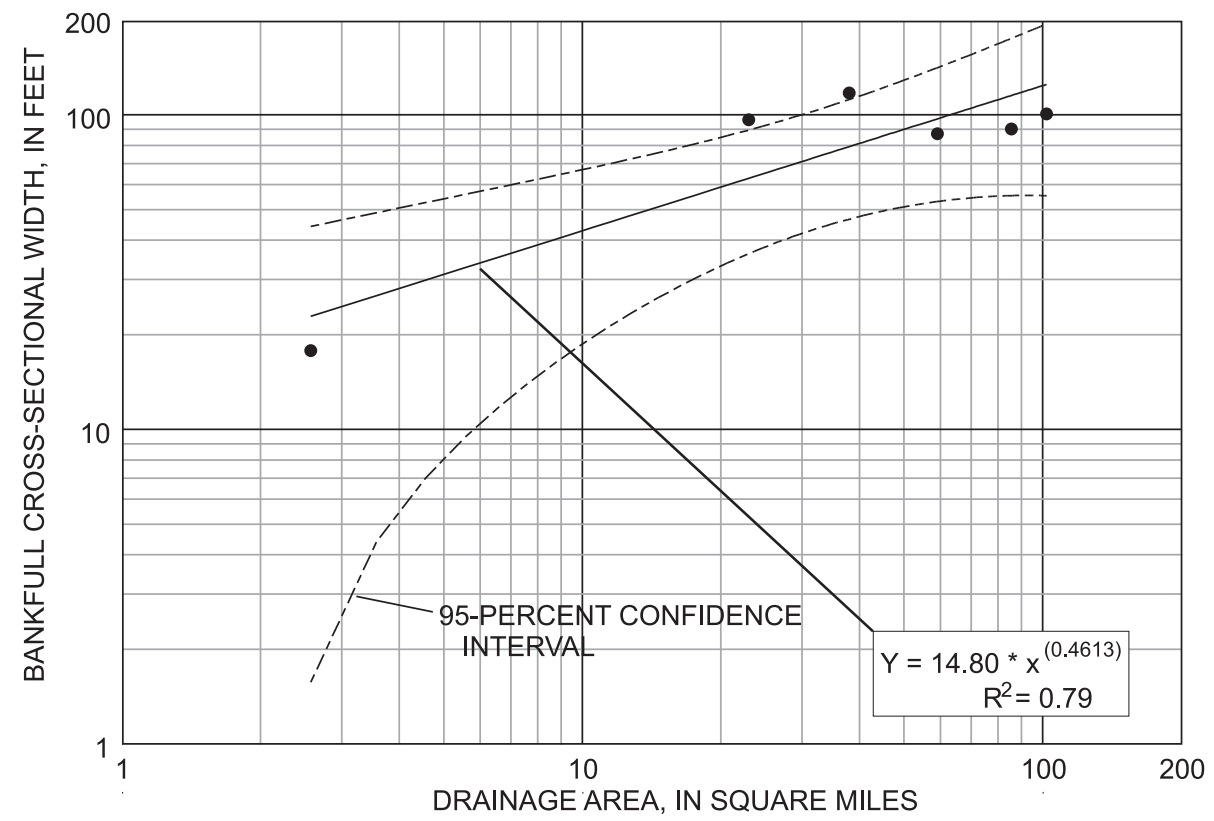

Figure 10. Regional curve representing relation between bankfull cross-sectional width and drainage area in non-urban, Lowland Sections of the Piedmont Physiographic Province, Pennsylvania and Maryland. 


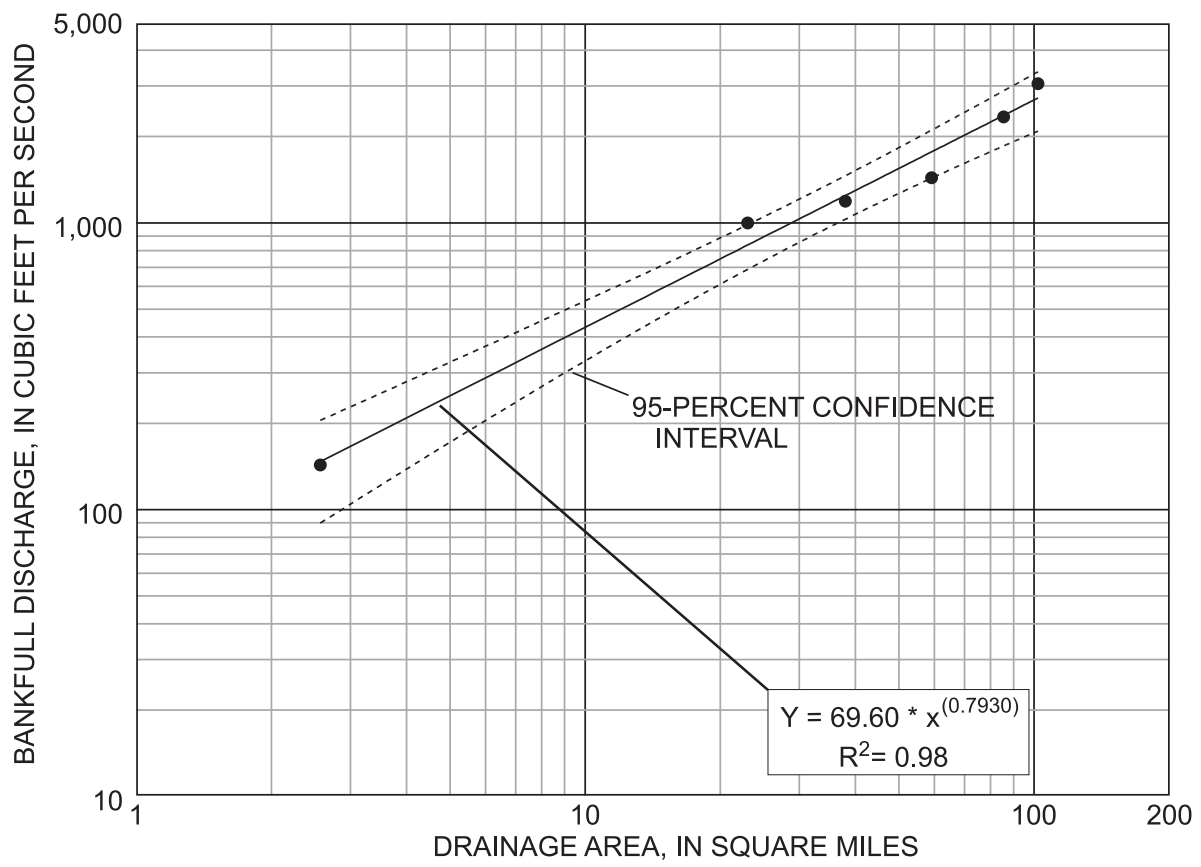

Figure 11. Regional curve representing relation between bankfull discharge and drainage area in non-urban, Lowland Sections of the Piedmont Physiographic Province, Pennsylvania and Maryland.

Regression diagnostics and visual inspection of the relations in figures 8 through 11 indicate the channel-characteristics data from the Sucker Run station have a strong effect on all the regression lines. Removing Sucker Run from the analysis improved the strength of the correlation between bankfull mean depth and drainage area as indicated by increasing the $\mathrm{R}^{2}$ to 0.99 ( $\mathrm{p}$-value $<0.001$, residual error $=0.02$, and $t$-value for the drainage area coefficient $=17.9$ ). Removing Sucker Run from the curves for bankfull discharge and bankfull cross-sectional area resulted in a reduction of the $R^{2}$ values but at least 90 percent of the variability of the data was explained by the drainage area. Without Sucker Run, the plot of bankfull channel width is basically flat and shows essentially no slopinglinear relation to drainage area.

\section{REFERENCE-REACH SELECTION}

New stream-restoration designs for impaired stream reaches frequently are based on a series of measurements made at streams of similar type that effectively accommodate streamflow and sediment without excessive channel erosion or deposition. The "stable" reach of stream, called a reference reach, can be on a different reach of the same stream as the project site or on a different stream that has similar runoff characteristics and valley type. Measurements at the reference reach are directed at quantifying conditions of the bankfull channel. Measured channel characteristics are presented as dimensionless ratios (for example, width/depth ratio) and extrapolated to the project site for incorporation into the restoration design. Use of dimensionless ratios allows for the transfer of channel characteristics among similar stream types. By incorporating dimensionless ratios that characterize an apparent stable reach of stream into the restoration design, practitioners assume the newly designed channel will function as effectively as the reference reach at transporting streamflow and sediment.

A 1,000-ft reach of stream that met all established criteria for a reference reach was identified on Bermudian Creek, less than $1 \mathrm{mi}$ upstream from the project site. The location of the reference reach and its proximity to the project site is shown on figure 12. A representative riffle cross section in the reference reach on Bermudian Creek is shown in figure 13 . Both the project site $\left(14.8 \mathrm{mi}^{2}\right)$ and the ference reach $\left(11 \mathrm{mi}^{2}\right)$ are in the Gettysburg-Newark Lowland Section of the Piedmont Physiographic Province. Most of the Bermudian Creek 

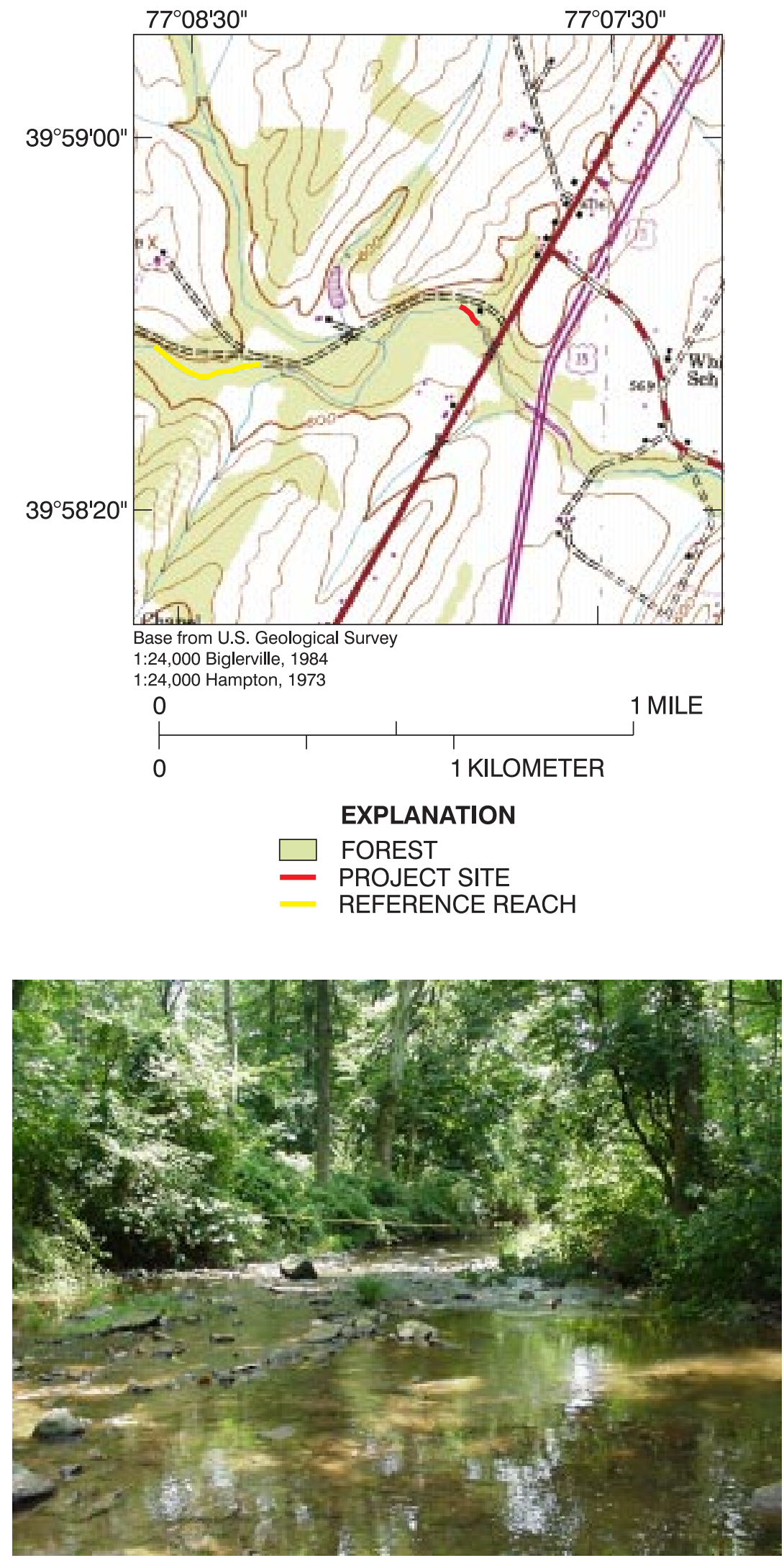

Figure 12. Location of project site and reference reach on Bermudian Creek, Adams County, Pennsylvania.
Figure 13. View looking downstream at cross section 526 of the reference reach on Bermudian Creek, Adams County, Pennsylvania. 
watershed upstream from the project site (83 percent) and the reference reach (76 percent) is in the Gettysburg-Newark Lowland Section of the Piedmont Physiographic Province. The remainder is in the South Mountain Section of the Blue Ridge Physiographic Province. Less than 1 percent of the watershed upstream from the reference reach and project site is classified as urban land use. Streamflow above the reference reach and the project site is not regulated, geology is predominantly triassicaged sandstone, siltstone, shales, and diabase with no carbonate rock, and about 29 percent of the watershed is covered by forest.

The reference reach is heavily wooded, point bars are well developed and vegetated, and excessive erosion or deposition is not evident. Riffles and pools have heterogeneous distributions of coarse- and fine-grained bed material. Geometry of the bankfull channel is fairly consistent throughout the reach. The bankfull channel is well defined throughout most of the reach as indicated by a flattening of the bank to a flood-plain profile, changes in depositional material, and the noticeable boundary of present woody and herbaceous vegetation. Channel dimensions of the riffle cross sections were applied to the Piedmont Lowland regional curves to confirm bankfull identification.

Three riffle and three pool cross sections were surveyed to define bank and channel characteristics. Pebble counts were conducted in each cross section to determine the particle distribution within the bankfull cross section. Representative data that characterize each cross section are shown in table 2. The longitudinal profile of the entire $1,000-\mathrm{ft}$ reach was surveyed. Channel features included in the survey were the thalweg (deepest part of the stream), edge of water, bankfull elevations, and other major channel characteristics. Channel-characteristic data from the longitudinal profile and other reach descriptor data collected during the site assessment are presented in table 3. Procedures to collect and/or compute data contained in table 3 followed those outlined by Harrelson and others (1994) and Rosgen (1996).

\section{COMPARISON OF ESTIMATES FROM LOWLAND REGIONAL CURVES AND DUNNE AND LEOPOLD REGIONAL CURVES FOR REFERENCE-REACH CHARACTERISTICS}

The bankfull cross-sectional area of $90.1 \mathrm{ft}^{2}$ estimated from the lowland regional curve for an $11-\mathrm{mi}^{2}$ basin was 18 percent less than the estimate from the Dunne and Leopold (1978) curve $\left(110 \mathrm{ft}^{2}\right)$. Estimates of bankfull mean depth $(2.00 \mathrm{ft})$ and bankfull width (44.7 ft) from the lowland regional curves differ by about -33 and 15 percent, respectively, from the Dunne and Leopold estimates of 3.00 and $39.0 \mathrm{ft}$. The estimate of the bankfull discharge from the lowland regional curve is $466 \mathrm{ft}^{3} / \mathrm{s}$. This estimate is 7 percent greater than the Dunne and Leopold estimate of $436 \mathrm{ft}^{3} / \mathrm{s}$.

Only cross-section surveys conducted within riffles are applied to regional curves. All applicable bankfull-channel dimensions, surveyed within the reference reach, are within the 95-percent confidence interval on the lowland regional curves.

The measured bankfull cross-sectional area for the three riffle cross sections at the reference reach was less than estimates from the lowland regional curve. All surveyed areas were within -17 percent of the estimated value; the average difference was -16 percent. Measured bankfull crosssectional areas averaged 31 percent less than the estimate from the Dunne and Leopold regional curve for cross-sectional area of the bankfull channel.

The bankfull mean depth for all three riffle cross sections at the reference reach ranged from 12 to 23 percent (average was 16.5 percent) less than estimates from the lowland regional curve. Measured bankfull mean depth averaged about 44 percent less than the estimate from the Dunne and Leopold regional curve for mean depth of the bankfull channel.

The bankfull widths measured at the three riffle cross sections within the reference reach ranged from 4 percent less to 9 percent more (average was 2 percent more) than estimates from the lowland regional curve. Measured bankfull width averaged about 17 percent less than the estimate from the Dunne and Leopold regional curve for bankfull width. 
Table 2. Cross-section data collected from assessment of reference reach on Bermudian Creek, Adams County, Pennsylvania

[ft, feet; $\mathrm{ft}^{2}$, feet squared; mm, millimeters; <, less than; +, actual width exceeds measured width; NA, not applicable]

\begin{tabular}{|c|c|c|c|c|c|c|c|c|c|c|c|c|c|c|}
\hline $\begin{array}{l}\text { Cross- } \\
\text { section } \\
\text { station } \\
\text { number }\end{array}$ & $\begin{array}{l}\text { Riffle } \\
\text { or } \\
\text { pool }\end{array}$ & $\begin{array}{l}\text { Rosgen } \\
\text { stream } \\
\text { type }^{1}\end{array}$ & $\begin{array}{l}\text { Bankfull } \\
\text { width } \\
\text { (ft) }\end{array}$ & $\begin{array}{l}\text { Mean } \\
\text { bankfull } \\
\text { depth } \\
\text { (ft) }\end{array}$ & $\begin{array}{l}\text { Maximum } \\
\text { bankfull } \\
\text { depth } \\
\text { (ft) }\end{array}$ & $\begin{array}{l}\text { Bankfull } \\
\text { cross- } \\
\text { sectional } \\
\text { area } \\
\left(\mathrm{ft}^{2}\right)\end{array}$ & $\begin{array}{c}\text { Width of flood } \\
\text { prone area }{ }^{1} \\
\text { (ft) }\end{array}$ & $\begin{array}{l}\text { D15 } \\
(\mathrm{mm})\end{array}$ & $\begin{array}{c}\text { D35 } \\
(\mathrm{mm})\end{array}$ & $\begin{array}{c}\mathrm{D} 50 \\
(\mathrm{~mm})\end{array}$ & $\begin{array}{c}\mathrm{D} 84 \\
(\mathrm{~mm})\end{array}$ & $\begin{array}{c}\text { D95 } \\
(\mathrm{mm})\end{array}$ & $\begin{array}{l}\text { Wetted } \\
\text { perimeter } \\
(\mathrm{ft})\end{array}$ & $\begin{array}{l}\text { Hydraulic } \\
\text { radius } \\
\text { (ft) }\end{array}$ \\
\hline 228 & Riffle & C4 & 45.0 & 1.70 & 2.33 & 76.4 & $190+$ & 0.1 & 7.6 & 15.0 & 96.0 & 211 & 47.1 & 1.62 \\
\hline 281 & Riffle & $\mathrm{C} 4$ & 42.9 & 1.76 & 2.11 & 75.5 & 88.4 & .1 & 3.6 & 8.9 & 87.7 & 171 & 43.9 & 1.72 \\
\hline 367 & Pool & NA & 41.5 & 1.51 & 3.23 & 62.6 & NA & $<.1$ & 2.0 & 12.0 & 39.2 & 81.6 & 42.7 & 1.47 \\
\hline 526 & Riffle & $\mathrm{C} 4$ & 48.6 & 1.54 & 2.82 & 74.6 & $151+$ & .1 & 2.7 & 8.0 & 89.7 & 256 & 43.3 & 1.72 \\
\hline 758 & Pool & NA & 32.7 & 2.02 & 3.26 & 66.0 & NA & .1 & 1.4 & 7.6 & 48.0 & 168 & 34.5 & 1.91 \\
\hline 791 & Pool & NA & 38.0 & 2.08 & 3.75 & 79.0 & NA & .4 & 11.1 & 26.4 & 140 & 233 & 44.0 & 1.80 \\
\hline
\end{tabular}

${ }^{1}$ Does not apply to pool cross sections. 
Table 3. Longitudinal-profile data collected from assessment of reference reach on Bermudian Creek, Adams County, Pennsylvania

[ft, feet; ft/ft, feet per foot; <, less than]

\begin{tabular}{|c|c|c|c|c|c|}
\hline & $\begin{array}{l}\text { Reach length } \\
\text { (ft) }\end{array}$ & $\begin{array}{l}\text { Bankfull slope } \\
\text { (ft/ft) }\end{array}$ & Sinuosity & $\begin{array}{l}\text { Valley slope } \\
\text { (ft/ft) }\end{array}$ & \\
\hline & 1,000 & 0.008 & 1.12 & 0.008 & \\
\hline $\begin{array}{l}\text { Average riffle } \\
\text { slope } \\
\text { (ft/ft) }\end{array}$ & $\begin{array}{l}\text { Average } \\
\text { pool slope } \\
\text { (ft/ft) }\end{array}$ & $\begin{array}{l}\text { Average pool- } \\
\text { to-pool } \\
\text { spacing } \\
(\mathrm{ft})\end{array}$ & $\begin{array}{l}\text { Average } \\
\text { meander } \\
\text { length } \\
(\mathrm{ft})\end{array}$ & $\begin{array}{c}\text { Average radius } \\
\text { of curvature } \\
(\mathrm{ft})\end{array}$ & $\begin{array}{l}\text { Average belt } \\
\text { width } \\
(\mathrm{ft})\end{array}$ \\
\hline 0.016 & 0.001 & 93.0 & 149 & 126 & 77.0 \\
\hline $\begin{array}{l}\text { Riffle slope } \\
\text { range } \\
\text { (ft/ft) }\end{array}$ & $\begin{array}{l}\text { Pool slope } \\
\text { range } \\
\text { (ft/ft) }\end{array}$ & $\begin{array}{l}\text { Pool-to-pool } \\
\text { spacing range } \\
\text { (ft) }\end{array}$ & $\begin{array}{c}\text { Meander } \\
\text { length range } \\
(\mathrm{ft})\end{array}$ & $\begin{array}{l}\text { Radius of } \\
\text { curvature } \\
\text { range } \\
\text { (ft) }\end{array}$ & $\begin{array}{l}\text { Belt width } \\
\text { range } \\
(\mathrm{ft})\end{array}$ \\
\hline $0.008-0.026$ & $<0.001-0.003$ & $39.0-150$ & $105-248$ & $60.0-340$ & $44.0-100$ \\
\hline
\end{tabular}

Streamflows associated with each cross section at the reference reach were computed from channel dimensions, representative channel roughness, and surface-water slope as surveyed throughout the reach. The computed bankfull discharges for each cross section ranged from 389 to $401 \mathrm{ft}^{3} / \mathrm{s}$; the average was $394 \mathrm{ft}^{3} / \mathrm{s}$. The lowland regional curve estimated $466 \mathrm{ft}^{3} / \mathrm{s}$ for the bankfull discharge in an $11.0-\mathrm{mi}^{2}$ watershed, about 18 percent greater than the average at the reference reach. The streamflow estimated from the Dunne and Leopold regional curve for the bankfull discharge $\left(436 \mathrm{ft}^{3} / \mathrm{s}\right)$ was 10.6 percent greater than the average computed streamflow for riffle cross sections at the reference reach.

\section{LIMITATIONS OF THE INVESTIGATION}

The small number of stations available for analysis is a major limiting factor in the strength of the results of this investigation. Including additional data in each regression would provide a better estimate of the relations among bankfull channel geometry, streamflow, and drainage area. Additional data points would most likely reduce the appreciable effect of Sucker Run. Subjective filtering criteria may have eliminated unnecessarily the streamflow-measurement stations that could have been included in the regional curves. Conversely, the land-use percentages characterizing the watershed may effect runoff characteristics at a much lower percentage than the criteria would indicate. For example, numerous studies suggest channel stability may be affected by urban land use and regulation at percentages lower than the 20 percent used in this report. As additional streamflow-measurement stations in the Piedmont Upland Section are assessed, the estimates provided by the relations of channel characteristics and drainage in the Lowland Sections of the Piedmont Physiographic Province may be improved by including these data. Statistical tests could be used to determine if the differences in runoff characteristics warrant separate regional curves for the Upland Section and the two Lowland Sections of the Piedmont Physiographic Province or if one allinclusive regional curve is appropriate.

The regional curves presented here should only be used for the confirmation of the bankfull channel at streams in the Lowland Sections of the Piedmont Physiographic Province. The assumption made for this investigation is that the bankfull discharge is within the 1- to 2-year recurrenceinterval range. Thorne and others (1997) state "the widely reported assertion that bankfull discharge occurs on average once every 1 to 2 years is now seen as an oversimplification." If runoff patterns at a streamflow-measurement station are such that the bankfull discharge may occur more often than this 1- to 2-year frequency, the recurrence-interval criteria did not substantiate identification of the bankfull channel as it was intended. In addition, land use and other basin characteristics upstream from the reach in consideration should be similar to those used for the selection criteria in this assessment. 
With regard to the reference reach, the qualitative designation of stability for the stream reach, without monitoring over time, may be inaccurate. The incorrect designation of the reference reach as a stable channel may introduce errors into the project design that is so closely related to the reference reach and its assumed stability. Use of these reference-reach data should be limited to project sites in areas having similar runoff characteristics and valley type.

\section{SUMMARY AND CONCLUSIONS}

The USGS, in cooperation with PaDEP, conducted a study to develop regional curves and characterize a reference reach. This study took place from 1999-2000 in the Lowland Sections of the Piedmont Physiographic Province in Pennsylvania and Maryland. A regional curve is a valuable tool used to confirm the identification of the bankfull channel. Regional curves were developed from channel-geometry and streamflow data collected at six USGS streamflow-measurement stations in the Gettysburg-Newark Lowland and Piedmont Lowland Sections of the Piedmont Physiographic Province (Manatawny Creek near Pottstown, Pa.01471980, French Creek near Phoenixville, Pa.01472157, Perkiomen Creek at East Greenville, Pa.01472198, West Branch Perkiomen Creek at Hillegas, Pa.-01472199, Sucker Run near Coatesville, Pa.-01480610, Big Pipe Creek at Bruceville, Md.01639500). The range in size of watersheds monitored by these stations is 2.57 to $102 \mathrm{mi}^{2}$. The bankfull channel was identified at each station by use of field indicators and confirmed by use of historical streamflow-measurement data. Representative cross sections were surveyed in riffles. Width, mean depth, and cross-sectional area of the bankfull channel were plotted as a function of drainage area and a "best-fit" regression line was applied to the data. The resulting regression line, and the corresponding equation defining that line, can be used to estimate the dimensions and streamflow of the bankfull channel at stream sites having similar runoff characteristics throughout the two Piedmont Lowland Sections when the drainage area is known.

A reference reach is a segment of a stream channel that appears to be effectively accommodating streamflow and sediment without excessive channel erosion or deposition. Channel characteristics defining a reference reach in the lowland sections of the Piedmont will serve as a template for design of a stream-restoration project on an impaired reach of Bermudian Creek. A reference reach meeting established criteria was identified on Bermudian Creek, less than $1 \mathrm{mi}$ upstream from the proposed stream-restoration site. Surveys of multiple cross sections and the longitudinal profile of the stream were conducted to characterize that channel. Bankfull channel dimensions of cross-sectional area (range $=62.6$ to $79.0 \mathrm{ft}$ ), width (range $=32.7$ to $48.6 \mathrm{ft}$ ), and mean depth (range $=1.51$ to $2.08 \mathrm{ft}$ ) varied throughout the reach. The particle distribution of the streambed material within each cross section was determined. Median particle size in each cross-section ranged from 7.6 to 26.4 millimeters. Monitoring changing channel characteristics over time is essential to confirm or refute the designation of "stable."

The concepts of regional curves and reference reaches can be valuable tools to support efforts in stream restoration. Practitioners of stream restoration need to recognize them as such and realize their limitations. Regional curves provide an estimate of bankfull-channel dimensions and streamflow. The curves developed for this study are based on limited highly variable data. The small number of streamflow-measurement stations used in these regressions limits the strength of the regional curves presented.

The use of channel-characteristics data from a reference reach without any monitoring data to document the stability of the reference reach over time is a topic of debate. Applying qualitative criteria to a selected reach of stream in an attempt to designate stability is subject to interpretation. In the early stages of stream restoration utilizing natural stream design, few other options are available. With the emphasis on the reference reach as a template for design, an enhanced network of stream reaches where long-term monitoring data are collected is essential to quantitatively document stream condition and improve confidence in the stability of the selected reference. 


\section{SELECTED REFERENCES}

Alexander, R.B., Brakebill, J.W., Brew, R.E., Smith, R.A., 1999, ERF1-Enhanced River Reach File 1.2 [online]: U.S. Geological Survey Open-File Report 99-457 [accessed May 17, 2001, at URL http:/ / water.usgs.gov/GIS/ metadata/usgswrd/erf1.html].

Andrews, E.D., 1980, Effective and bankfull discharges of streams in the Yampa River Basin, Colorado and Wyoming: Journal of Hydrology, v. 46, p. 311-330.

Dunne, T., and Leopold, L.B., 1978, Water in Environmental Planning: San Francisco, Calif., W.H. Freeman, 818 p.

Federal Interagency Stream Restoration Working Group, 1998, Stream corridor restoration, principles, processes, and practices: GPO Item No. 0120-A; SuDocs No. A 57.6/2:EN 3/PT.653. ISBN-0-934213-59-3.

Gordon, N.D., McMahon, T.A., and Finlayson, B.L., 1992, Stream hydrology, an introduction for ecologist: Chichester, England, John Wiley and Sons, 526 p.

Hammer, T.R., 1972, Stream channel enlargement due to urbanization: Water Resources Research, v. 8, p. 1,530-1,540.

Harrelson, C.C., Rawlins, C.L., and Potyondy, J.P., 1994, Stream channel reference sites-An illustrated guide to field technique: U.S. Forest Service, General Technical Report RM-245, 61 p.

Leopold, L.B., 1994, A view of the river: Cambridge, Mass., Harvard University Press, 298 p.
Pennsylvania Department of Transportation, 1997, 1997 Pennsylvania cartographic/GIS information: Harrisburg, Pa., Bureau of Planning and Research, Publication BPRCD-97.

Rosgen, D., 1996, Applied river morphology: Minneapolis, Minn., Printed Media Companies, $352 \mathrm{p}$.

Sevon, W.D., comp., 2000, Physiographic provinces of Pennsylvania (4th ed.) [online]:

Pennsylvania Geologic Survey, map 13, scale 1:2,000,000 [accessed Oct. 24, 2000, at URL http://www.denr.state.pa.us/ topogeo/map13/13pls.htm].

Thorne, C.R., Hey, R.D., and Newson, M.D., 1997, Applied fluvial geomorphology for river engineering and management: Chichester, England, John Wiley and Sons, 376 p.

U.S. Geological Survey, 1996, National land cover data [online]: U.S. Geological Survey [accessed May 17, 2001, at URL http://edcwww.cr.usgs.gov/programs/lccp /nationallandcover.html].

Wolman, M.G., 1954, A method of sampling coarse river-bed material: Transactions of the American Geophysical Union, v. 35, p. 951956.

1955, The natural channel of Brandywine Creek Pennsylvania: U.S. Geological Survey Professional Paper 271, 56 p. 